\title{
THE ISSUES OF QUALIFICATION AND LEGAL PROCEEDINGS OF ILLIGAL ACTIONS AIMED AT NON-DECLARATION OF GOODS, VEHICLES MOVING THROUGH THE CUSTOMS BORDER OF UKRAINE
}

\section{Lipynskyi V. V.}

\section{INTRODUCTION}

Systematic study of foreign trade operations and determination of their expediency, control of routes of movement of goods and vehicles, strengthening control over the implementation of foreign trade operations with certain highly liquid goods on a permanent basis is carried out by the State Fiscal Service of Ukraine (hereinafter - SFS). It should be noted that according to the Resolution of the Cabinet of Ministers of Ukraine dated from December 18, 2018, № 1200 “On Establishment of the State Tax Service of Ukraine and the State Customs Service of Ukraine", the State Fiscal Service of Ukraine is being reorganized by dividing it into two services: State Tax Service of Ukraine and the State Customs Service of Ukraine; newly created services are the central bodies of the executive power for ensuring the implementation of state policy in the tax and customs area (respectively); the direction and coordination of the services will be implemented by the Cabinet of Ministers of Ukraine through the Minister of Finance of Ukraine; the services are the successors to the rights and responsibilities of the reorganized SFS in their respective fields of activity. ${ }^{1}$ On March 6, 2019, the Cabinet of Ministers of Ukraine approved Resolution № 227 “On Approval of the Regulations on the State Tax Service of Ukraine and the State Customs Service of Ukraine".

The analysis of exposed attempts of illegal movement of goods and minimization of taxes during their import it was revealed a systemic

${ }^{1}$ Про утворення державної податкової служби України та державної митної служби України: Постанова Кабінету Міністрів України від 18 грудня 2018 р. № 1200 / Кабінет Міністрів України. URL: http://zakon.rada.gov.ua/laws/show/12002018-\%D0\%BF (дата звернення: 04.04.2019). 
problem related to the presence in the territory of Ukraine of goods, vehicles, customs clearance of which was not carried out, due to which the state budget did not receive proper customs payments in full. One of the reasons of this situation in the domestic market of imported goods is the using by dishonest subjects of foreign economic activity gaps in the current legislation and committing unlawful actions aimed at not declaring goods and vehicles ${ }^{2}$.

During the 12 months of 2018, the Customs of the State Customs Service detected 48.9 thousand violations of customs rules with the value of offenses amounting to 3.4 billion UAH. Compared to the corresponding period of the previous year, the number of drawn up protocols on violation of customs rules increased by $51 \%$, and the value of the offense was halved. In 5.4 thousand cases of violation of customs rules offenses It was temporarily seized subjects of offenses for the amount of 914 million UAH. The amount of temporarily seized offenses increased by $24 \%$. The most common are cases of illegal movement across the customs border of manufactured goods. During the specified period, for the commission of such violations it was seized the goods in the amount of 568.6 million hryvnia. Vehicles were withdrawn in the amount of UAH 149.9 million, foodstuffs - by UAH 119.3 million, currencies - UAH 76 million. 39.2 thousand cases of violation of customs rules were considered by the Customs of the State Customs Service, which is $81 \%$ more than for the same period of 2017. 6.2 thousand cases of violation of customs rules in the amount of 2.5 billion UAH were submitted to the court by the customs. As a result of litigation of cases of violation of customs rules, the court decided to impose fines and confiscation in the amount of UAH 483.8 million.

One of the effective methods of counteracting the customs offense is cooperation and exchange of information with the competent authorities of foreign countries in the framework of mutual administrative assistance, which ensures the prevention and detection of illegal export-import transactions and the fact of non-payment of the obligatory customs payments to the budget. According to the results of international cooperation, over 712 cases of violation of customs rules

2 Ліпинський В.В. Проблемні питання кваліфікації протиправних дій, спрямованих на недекларування товарів, транспортних засобів, що переміщуються через митний кордон України. Правова позиція. 2017. № 1 (18). С. 44. 
amounting to UAH 686.5 million were initiated in the 12 months of 2018. In addition, non-payment of over UAH 21.2 million of compulsory customs payments was established in the course of international cooperation. 208 materials of the received responses were submitted to the territorial units of the State Customs Service for establishing the presence of signs of criminal offenses and carrying out control and verification measures. According to the results of materials processing, 29 criminal proceedings have already been initiated by the territorial units of the State Fiscal Service ${ }^{3}$.

\section{The Issues of Qualification of Actions Aimed at Non-Declaration of Goods, Vehicles Moving Across the Customs Border of Ukraine}

The concept of "violation of customs rules" is contained in Art. 458 of Customs Code of Ukraine (hereinafter - CCU). According to this article Customs offense means an administrative offense that is unlawful, wrongful (deliberate or inadvertent) acts or omissions that impinge on the procedure laid down in this Code and other legislative acts of Ukraine for movement of goods, means of transport for commercial use across the customs border of Ukraine, their presentation to the revenue and duties authorities for customs supervision and customs clearance, as well as handling of goods that are placed under customs control or for whose control the revenue and duties authorities are responsible under this Code or other laws of Ukraine, and for which this Code provides for administrative liability ${ }^{4}$.

Set of elements of an offense includes signs characterizing the external act of a person's behavior, its orientation, consequences, and signs characterizing the offender himself and his mental attitude to the crime. The signs of the Set of elements of an offense are combined into four groups (elements) that characterize: the object of violation of customs rules, the objective side of violation of customs rules, the subject of violation of customs rules, the mental element of violation of

\footnotetext{
${ }^{3}$ Інформація щодо стану боротьби з митними правопорушеннями упродовж 2018 року Державної фіскальної служби України. Київ, 2019. URL: http://sfs.gov.ua/media-tsentr/novini/365795.html (дата звернення: 04.04.2019).

${ }^{4}$ Митний кодекс України: Закон України від 13 березня 2012 р. № 4495-VI / Верховна Рада України. URL: http://zakon.rada.gov.ua/laws/show/4495-17 (дата звернення: 04.04.2019).
} 
customs rules. All these elements of customs rules offense constitute an inextricable unity. The presence of these elements is necessary to qualify a specific act as a violation of customs rules.

The object of violation of customs rules are public relations that arise in the field of public administration, are protected by the legislation that establishes customs rules, and which causes damage in the case of customs offenses. According to paragraph 28 of Art. 4 CCU 'Customs rules' means the rules, established by the Code and other legislative acts of Ukraine, that apply to the movement of goods and means of transport for commercial use across the customs border of Ukraine, their presentation to the revenue and duties authorities for customs control and customs clearance as well as to the processing of operations with goods that are placed under customs control or assigned to the revenue and duties authorities by the Code and other laws of Ukraine for supervision.

According to Art. 257, $266 \mathrm{CCU}$ the declarant is obliged to declare the goods, that is, to declare in the prescribed form accurate information about the goods, the purpose of their movement, as well as information necessary for the carrying out their customs control and customs clearance.

Responsibility for the non-declaration of goods, commercial vehicles moving across the customs border of Ukraine, i.e. non-declaration on the established form of accurate and authentic information (presence, name or title, quantity, etc.) of goods, commercial vehicles subject to obligatory declaration in case of moving across the customs border of Ukraine, provided for by Art. 472 of CCU. Sanction of Art. 472 CCU provides for the imposition of a fine of 100 percent of the value of these goods, vehicles with the confiscation of these goods, vehicles.

Therefore, the object of this offense is the procedure established by the CCU for declaring goods, vehicles transported through the customs border of Ukraine.

The objective side of violations of customs rules is the set of statutory features that characterize the outward manifestation of an act that infringes on the objects of legal protection, as well as the objective conditions of that encroachment. The objective side of the offense under Art. 472 of the CCU, is the failure to declare in the prescribed form accurate and reliable information (presence, name or name, quantity, etc.) of goods, vehicles subject to obligatory declaration in case of their movement across the customs border of Ukraine. 
Non-declaration of goods, vehicles transported across the customs border of Ukraine is the failure to declare, in the established form, accurate information about goods and vehicles, as well as information necessary for their customs control and customs clearance.

According to item 3.5 of the Procedure of filling in customs declarations on the form of the single administrative document approved by the order of the Ministry of Finance of Ukraine on 30.05.2012 № 651, registered at the Ministry of Justice of Ukraine on 14.08.2012 under № 1372/21684 (hereinafter - the Procedure) the necessity to fill in a certain information field of the customs declaration by the declarant shall be determined in accordance with the rules for filling in the information fields given in Chapter II of this Procedure, on the basis of the direction of movement, the customs regime chosen, the presence or absence of a description of this information field in the relevant Chapter II of this Procedure and the existence of reservations in the text of the description of this information field. Customs authorities are not allowed to establish the procedure for filling in the information fields of the customs declaration and to determine the peculiarities of filling it in other way than those which are specified in the Procedure, as well as to make requirements to the declarant on filling in to the customs declaration information not provided for by the Procedure.

It should be noted that providing documents containing false information about the name of the goods, their weight (taking into account allowable losses under appropriate storage and transportation conditions) or the quantity, country of origin, consignor and/or recipient, quantity packages, their markings and numbers, false information necessary to determine the product code according to UKT FEA and its customs value as a basis for the movement of goods to the body of income and fees is the basis for considering the of the presence of signs of violation of customs rules, provided for by Art. $483 \mathrm{CCU}$.

In accordance with Art. $257 \mathrm{CCU}$ declaration is carried out by declaring in the prescribed form (written, oral, by taking action) accurate information about the goods, the purpose of their movement across the customs border of Ukraine, as well as information necessary for the implementation of their customs control and customs clearance. When using the written declaration form, both electronic documents and paper documents can be used. 
The conditions and procedure for declaring, the list of information required for customs control and customs clearance are determined by the CCU. The regulations on customs declarations and the forms of these declarations are approved by the Cabinet of Ministers of Ukraine, and the procedure for filling out such declarations and other documents used in the customs clearance of goods, commercial vehicles is approved by the central executive body, which ensures the formation and implementation of state tax and customs policies.

The Decree of the Cabinet of Ministers of Ukraine from May 21, 2012 № 450 approved the Regulation on Customs Declarations (hereinafter - the Regulations), which defines the requirements for the registration and use of customs declarations, on the basis of which goods transported (shipped) across the customs border of Ukraine by enterprises, and other goods declared in accordance with the legislation of Ukraine by submission of the customs declaration provided for the enterprises, as well as the procedure for amending the customs declarations, revoking them and declaring them invalid.

Goods are declared by providing to the customs authority:

- customs declaration on the form of the single administrative document;

- -or M-16 customs declaration;

- or a written application in accordance with Annex 1 to the Regulations;

- or a customs declaration for the written declaration of goods moving across the customs border of Ukraine by citizens for personal, family and other needs not related to the pursuit of business;

- or other document that may be used instead of a customs declaration in accordance with the law.

When moving (forwarding) goods across the customs border of Ukraine by citizens, the customs declaration on the form of a single administrative document shall be filled in cases when such goods are declared in accordance with the Customs Code of Ukraine and the Regulation with the submission of the customs declaration stipulated by the legislation of Ukraine for enterprises, as well as for declaration of goods (including personal use transport vehicles) imported into the customs territory of Ukraine and subject to official registration in accordance with the law. 
In particular, citizens are allowed to import vehicles of personal use for transit through the customs territory of Ukraine, subject to their written declaration in the manner prescribed for citizens, and depositing into the account of the authority revenue and fees, having commited the passage of such vehicles to the customs territory of Ukraine, a cash deposit in the amount of customs payments which must be payed when importing such vehicles into the customs territory of Ukraine for the purpose of free circulation. These requirements do not apply to vehicles permanently registered with the relevant registration authorities of a foreign state, which is confirmed by the relevant document ${ }^{5}$.

Standard customs declaration shall mean a customs declaration containing the particulars (data), sufficient to complete the customs clearance of goods and means of transport for commercial use under the customs procedure for which they were declared.

Advance customs declaration (other document that can be used instead of the customsdeclaration under Article 94 of the Code) shall be filed prior to importation of goods, meansof transport for commercial use (including for transit) to Ukraine or after their importation if they are in the territory of the Ukrainian border checkpoint.

Advance customs declaration shall be filed by the declarant or the person authorised by him to the revenue and duties authority, in whose operation area the goods, means of transport for commercial use are presented to customs clearance, for the purposes of conducting risk analysis and accelerating the customs formalities. When filing an advance customs declaration, the liability of the declarant or the person authorised by him for the accuracy of information contained in that declaration shall occur after:

(1) release of goods, means of transport for commercial use under the declared customs procedure without presenting them to the revenue and duties authority processing such declaration, or

(2) release of goods, means of transport for commercial use under the declared customs procedure after the presentation to the revenue and duties authority processing such advance customs declaration, but without customs examination by that revenue and duties authority, or

5 Ліпинський В.В. Правові аспекти кваліфікації дій, пов'язаних із користуванням чи розпорядженням транспортними засобами особистого користування, ввезеними на митну територію України в митному режимі "транзит". Правова позиичія. 2016. № 1 (16). С. 70. 
(3) notification to the declarant, or person authorised by him, by the revenue and duties authority processing such advance customs declaration of customs examination of the presented goods, means of transport for commercial use.

If the declarant or the person authorised by him does not have accurate particulars about the characteristics of the goods needed to fill in standard customs declaration, he may file a temporary customs declaration for the following goods to the revenue and duties authority, provided that it contains information sufficient for placing them for the declared customs procedure and under obligation to file an additional declaration within 45 days from the date of processing of temporary customs declaration (Part 1 of Art. $260 \mathrm{CCU}$ ).

In case of providing temporary or periodic customs declaration, the declarant or the person authorised by him shall, during the period established in accordance with the Code, file to the revenue and duties authority an additional declaration, which contains accurate particulars about goods declared under cover of any previous temporary or periodic customs declaration, which would have been filed under cover of a standard customs declaration. Goods moved across the customs border of Ukraine shall be declared to the revenue and duties authority, responsible for customs clearance of those goods.

Upon acceptance of the customs declaration by the revenue and duties authority it shall be a document that certifies the facts of legal significance, and the declarant or the person authorised by him shall be held liable for indicating false information in that declaration. In case of violation of customs rules regarding goods, means of transport for commercial use declared in the customs declaration, amendment, revocation and invalidation of that declaration until the end of proceedings in appropriate cases shall be prohibited. Proceedings in cases of violation of customs rules shall not be initiated, where the declarant or the person authorised by him independently applied to the revenue and duties authority to amend the customs declaration in the following cases:

- Amendments to the customs declaration accepted by the revenue and duties authority shall be allowed until the completion of customs clearance of goods and means of transport for commercial use under the declared customs procedure and within three years from the date of completion of customs clearance. Amendments shall relate 
only to goods, means of transport for commercial use specified in the customs declaration.

- If, after the release of goods for free circulation, the customs supervision of which was carried without customs examination, the declarant has identified goods moved across the customs border of Ukraine and not specified in the customs declaration, at the written request of the declarant and with the authorisation of the revenue and duties authority amendment shall be made to the customs declaration on the increase in the number of goods released for free circulation in the customs territory of Ukraine in connection with the identification of undeclared goods.

- 4. Amendments to the customs declaration that affect the application of tariff and/or nontariff regulation of foreign economic activity to the goods shall be provided that such regulation is observed.

Subjects of administrative liability for customs offenses provided for in Art. 472 of CCU may be citizens who at the time of the offense have attained 16 years of age, and corporate officials in case of customs offenses by the entities. However, these categories enter into relations with the customs when declaring goods, vehicles for commercial purposes. 'Declarant' means the person making the customs declaration in his/her own name or the person in whose name a customs declaration is made.

Declarants may be:

(1) a resident who entered into the agreement or oh whose behalf it ientered into in the case of movement of goods, means of transport for commercial use across the customs border of Ukraine or change of the customs procedure for goods based on foreign trade agreement entered into by a resident;

(2) a person who under the laws of Ukraine is entitled to perform legally significant action on his behalf in relation to goods, means of transport for commercial use in other cases.

Entities may be declarants, provided that they are registered with the revenue and duties authorities of Ukraine.

The person authorised to declare goods, means of transport for commercial use on behalf of the declarant shall have the same duties, rights and bear the same liability as the declarant. 
The subjective side of violations of customs rules is characterized by the mental attitude of a person to commit an offense:

1) guilt - a person's mental attitude to a committed action or inaction and its consequences, expressed in the form of intent or negligence;

2) motive - the internal motivation of a person who created the psychological prerequisites for committing an offense;

3) purpose - a consequence that the person seeks to achieve when committing an offense.

The offense under Art. 472 of $\mathrm{CCU}$, may be committed intentionally or by negligence.

\section{Some Issues of Legal Proceeding of Customs Rules Violation Cases, Established on the Grounds of Art. 472 of the Customs Code of Ukraine}

According to an Art. 472 of CCU failure to declare goods, means of transport for commercial use moved across the customs border of Ukraine, i.e. failure to declare, in the prescribed form, accurate and authentic information (availability, name or title, quantity, etc.) of goods, means of transport for commercial use subject to mandatory declaration when moved across the customs border of Ukraine.

Penal clause of the Art. 472 of CCU provides for entailing a fine amounting to 100 per cent of the cost of such goods, means of transport with their confiscation. According to the Part 3 of Art. $465 \mathrm{CCU}$ confiscation of goods, means of transport referred to in paragraph 3 of Article 461 of this Code shall apply regardless of whether those goods and means of transport are owned by the offender.

For example, a Ukrainian citizen Mr. M. returned to Ukraine from Italy, where he was in private affairs. The "red channel" was chosen as the form of customs control. The citizen filled out a customs declaration stating the vehicle, foreign currency and the availability of personal belongings in the amount of 55 colli. In oral questioning, the citizen confirmed the information specified in the customs declaration and denied the presence of any other goods, including those subject to obligatory declaration or movement which is prohibited or restricted through the customs border of Ukraine.

When carrying out customs control of the vehicle, in addition to the personal items declared by him, undeclared goods estimated by the 
amount more than 54 thousand UAH were discovered. Based on this fact, Zakarpattya Customs drew up a protocol on violation of customs rules for the specified person on the grounds of an offense under Art. 472 of CCU.

In his written explanations, the citizen explained that he had transported undeclared goods to Ukraine at the request of an unfamiliar Italian citizen. In the future, the offender was supposed to send the goods by mail to the address indicated on the packages of goods, he did not intend to violate customs legislation.

By the decision of the Uzhgorod Inter-districtCourt of the Zakarpattya Region in the case of violation of the customs rules of a citizen of Ukraine, Mr.M. was found guilty of violating the customs rules provided for in Article 472 of CCU, an administrative penalty was imposed in the form of a fine of $100 \%$ of the cost of goods with their confiscation.

Part 2 of Art. 467 of CCU defined that if the cases of customs offenses in accordance with Article 522 of the Code are dealt with by the courts (judges), administrative penalty for customs offenses may be imposed not later than three six from the date of the offense, and if the courts (judges) deal with the cases of continuing customs offenses, including those provided for in Articles 469, 477-485 of the Code, not later than six months from the date when those offenses were discovered.

Continuing offenses are misconduct associated with a long, continuous failure to fulfill obligations stipulated by a legal norm. Such offenses are terminated either by the performance of established duties, or by bringing the perpetrator to justice.

Offenses are recognized as continuing, which, starting with any illegal action or inaction, are then carried out continuously by default. The initial moment of such an act may be an active action or inaction, when the guilty person either does not perform a specific duty assigned to her, or performs it not completely or incorrectly.

Stipulated by an Art. 472 TCU violation of customs rules, consists in the non-declaration of goods, commercial vehicles that move across the customs border of Ukraine, characterized by a one-time action at a certain time.

Thus, this violation of customs regulations cannot be considered ongoing, it is terminated with the submission of a declaration to the 
customs authority, and therefore, an administrative penalty can be imposed no later than six months from the date of its commission.

For example, the Galytsky District Court of Lviv city issued a ruling in the case of violation of customs regulations. According to this decision, "... after hearing a representative of the Lviv Customs, having examined the case file, the court concluded that Mrs.G.'s actions contained signs of an offense under Art. 472 of CCU, however, the proceedings are subject to termination on the following grounds.

The court found that according to the protocol on violation of customs rules, made on September 25.09.2014, Mrs.G.'s administrative offense was committed on September 25.09.2014, and the case files came with a six-month expiration - September 02.09. 2015.

Mrs. G.'s guilt in committing the offense under Art. 472 of the $\mathrm{CCU}$, is confirmed by the protocol on violation of customs rules, customs declaration, the act of carrying out inspection (reinspection) of goods, vehicles, hand luggage and luggage.

This administrative offense is not continuous and more than six months have passed since its commission. Consequently, the deadline for the imposition of an administrative penalty has expired; in this regard, the proceedings in the case must be closed".

According to the Part 1 Art. 268 of CCU Mistakes in the customs declaration that did not result in improper relief from customs duties or their reduced amount, failure to comply with tariff and/or non-tariff regulation of foreign economic activity shall not entail penalties stipulated by this Code and other legislative acts of Ukraine, save as provided for in Section 3 of this Article (i.e. if a person regularly (more than twice a month) makes mistakes in the customs declaration mentioned in Section 1 of this Article (except spelling mistakes), the revenue and duties authority shall apply to such person the penalties stipulated by this Code and other legislative acts of Ukraine).

For example, considering a case of violation of customs rules Kovpakivsky District Court of Sumy city established: "With the customs declaration attached to the case file dated 08/28/2015, completed personally by Sh., It is seen that in paragraph 3.1 he indicated 33,100 US dollars. Although in reality he imported into Ukraine 63,000 US dollars and 8,000 hryvnias. Thus, he did not indicate USD 29,900 and UAH 8,000 in the declaration. 
Objecting to the administrative protocol, both Sh. and his defense attorney noted that in this case there was an error in the customs declaration, relieved Sh. of liability for this violation of customs rules, because this error did not cause any harm to the state of Ukraine and this error leads to of unlawful exemption from customs payments or a reduction in their size, sinceArt.268 of CCU provides for mistakes in the customs declaration that did not result in improper relief from customs duties or their reduced amount, failure to comply with tariff and/or non-tariff regulation of foreign economic activity shall not entail penalties stipulated by this Code and other legislative acts of Ukraine, save as provided for in Section 3 of this Article.

However, this position is erroneous, based on the following:

So, Art. 472 of CCU provides liability for failure to declare goods, means of transport for commercial use moved across the customs border of Ukraine, i.e. failure to declare, in the prescribed form, accurate and authentic information (availability, name or title, quantity, etc.) of goods, means of transport for commercial use subject to mandatory declaration when moved across the customs border of Ukraine.

That is, the indicated norm of the law provides for a formal composition of an administrative offense, and not material in the form of the onset of any negative consequences or damage to the state.

According to a Part 8 of Art.264 of CCU Upon acceptance of the customs declaration by the revenue and duties authority it shall be a document that certifies the facts of legal significance, and the declarant or the person authorised by him shall be held liable for indicating false information in that declaration".

\section{CONCLUSIONS}

Summarizing the above, it can be stated that upon detection of the fact of non-declaration on the established form of accurate and reliable information (presence, name or name, number, etc.) of goods, commercial vehicles, which are subject to obligatory declaration in case of movement across the customs border of Ukraine, there is an offense under Art. 472 of CCU.

During the legal proceeding of cases of violation of customs rules instituted under Art. $472 \mathrm{CCU}$, the court takes into account the quality of proceedings in the case of violation of customs rules, namely: 
1) timely, comprehensive, complete and objective clarification of the circumstances of each case;

2) its decision in compliance with the requirements of the law;

3 ) ensuring the execution of the decision;

4) identification of the causes and conditions conducive to committing violations of customs rules;

5) the prevention of such offenses.

Timeliness implies compliance with the procedural deadlines: deadline for imposing administrative penalties; terms of consideration of the case; terms of consideration of the case

The circumstance obliges the body or official to investigate all the facts and circumstances of the violation of customs rules relevant to the resolution of the case.

The completeness of the clarification of the circumstances of each case is achieved through the use of all procedural actions. When resolving disputes in claims for decisions, actions or inaction of subjects of authority in the provision of administrative services, the courts, in accordance with the Part 3 of Article 2 of the Code of Administrative Proceedings of Ukraine, must check whether they are accepted (committed): 1) on the basis, within the powers and in the manner determined by the Constitution and laws of Ukraine; 2) using the authority for the purpose with which that power was conferred; 3) substantiated, that is, taking into account all the circumstances that are relevant for the decision (action); 4) impartial (impartial); 5) in good faith; 6) judiciously; 7) respecting the principle of equality before the law, preventing all forms of discrimination; 8) in proportion, in particular, with respect to the necessary balance between any adverse effects on the rights, freedoms and interests of the person and the purposes to which this decision is directed (action); 9) taking into account the right of a person to participate in the decision-making process; 10) in a timely manner, ie within a reasonable time ${ }^{6}$.

Objectivity is achieved due to an impartial attitude to facts and circumstances, clarified during production, and an impartial attitude

6 Легеза Є.О. Деякі аспекти оскарження результатів надання публічних послуг в судовому порядку. Науковий вісник Херсонського державного університету. Серія «Юридичні науки». 2016. № 1. Т. 3. С. 11. 
towards a person is brought to administrative responsibility for violation of customs rules.

The proceedings on cases of violation of customs rules should be carried out on the basis of strict compliance with the law. When considering a case on violation of customs rules, the body (official) is required to ascertain whether an administrative offense was committed, whether the person is guilty of its commission, whether it is subject to administrative liability, whether there are circumstances mitigating and/or aggravating liability, are there any grounds for exemption of the person who committed the offense from administrative responsibility, as well as to find out other circumstances relevant to the proper resolution of the case.

It should be noted that the revenue and duty bodies participate in the implementation of the decision, not only in cases when it is issued by this body, but also at the stage of the proceedings, when officials have the right to temporarily seize goods, commercial vehicles and documents, and appoint expert examinations etc.

The assignment to identify the causes and conditions conducive to committing violations of customs rules is to comply with the provisions of Art. 282 of the Code of Administrative Offenses of Ukraine, which stipulates that the body (official) considering the case, having established the reasons and conditions that contributed to the commission of an administrative offense, makes proposals to the relevant state body or local government body, public organization or official to take measures to eliminate these reasons and conditions. It is must be notified about the measures taken within a month from the date of receipt of the proposal to the body (official) that made the proposal.

For solving the problem of the non-declaration of goods, vehicles moving across the customs border of Ukraine, it is beneficial to organize an operational exchange of information between the SFSU and the State Border Service of Ukraine as well as the customs administrations of foreign countries.

\section{SUMMARY}

A systematic study of foreign economic operations and determining their appropriateness, tracking the routes of movement of goods and vehicles, strengthening control over foreign economic operations with 
certain highly liquid goods on an ongoing basis is carried out by the State Fiscal Service of Ukraine.

Based on the analysis of convicted attempts to illegally movement goods and minimize taxes when importing them, a systemic problem was discovered related to the presence in the trade in Ukraine of goods, vehicles which were not customs cleared, due to which the state budget did not receive in full the proper customs payments.

One of the reasons for this situation in the domestic market of imported goods is the use by unscrupulous entities of foreign economic activity, gaps in the current legislation and the commission of illegal actions aimed at the non-declaration of goods and vehicles.

Given the above, the issues of qualification and judicial proceedings of illegal actions aimed at the non-declaration of goods, vehicles moving across the customs border of Ukraine were examined and analyzed. Based on the analysis, the corresponding conclusions are made and suggestions are given.

\section{REFERENCES}

1. Про утворення державної податкової служби України та державної митної служби України: Постанова Кабінету Міністрів України від 18 грудня 2018 р. № 1200 / Кабінет Міністрів України. URL: http://zakon.rada.gov.ua/laws/show/1200-2018-\%D0\%BF (дата звернення: 04.04.2019).

2. Проблемні питання кваліфікації протиправних дій, спрямованих на недекларування товарів, транспортних засобів, що переміщуються через митний кордон України. Правова позиція. 2017. № 1 (18). С. 43-52.

3. Інформація щодо стану боротьби 3 митними правопорушеннями упродовж 2018 року Державної фіскальної служби України. Київ, 2019. URL: http://sfs.gov.ua/media-tsentr/novini/ 365795.html (дата звернення: 04.04.2019).

4. Митний кодекс України: Закон України від 13 березня 2012 p. № 4495-VI / Верховна Рада України. URL: http://zakon.rada.gov.ua/laws/show/4495-17 (дата звернення: 08.08.2018).

5. Питання, пов'язані із застосуванням митних декларацій: Постанова Кабінету Міністрів України від 21 травня 2012 № 450 / 
Кабінет Міністрів України. URL: http://www.zakon.rada.gov.ua (дата звернення 04.04.2019).

6. Ліпинський В.В. Правові аспекти кваліфікації дій, пов'язаних із користуванням чи розпорядженням транспортними засобами особистого користування, ввезеними на митну територію України в митному режимі "транзит". Правова позиція. 2016. № 1 (16). С. 68-73.

7. Лист Державної фіскальної служби України від 31 березня 2016 p. № 11040/7/99-99-26-03-02-17. URL: http://www.sfs.gov.ua/ zakonodavstvo/mitne-zakonodavstvo/listi/_ (дата звернення: 10.04.2016).

8. Легеза Є.О. Деякі аспекти оскарження результатів надання публічних послуг в судовому порядку. Науковий вісник Херсонського державного університету. Серія «Юридичні науки». 2016. № 1. Т. 3. С. 34-37.

9. Сучасний стан та перспективи розвитку митних правовідносин в Україні : колективна монографія / за заг. ред. Д.В. Приймаченка. Дніпро: Видавничий дім «Гельветика», 2018. 272 с.

10. Атаманчук Г. В. Теория государственного управления : курс лекций. М. : Юрид. лит., 1997. 428 с.

11. Про Концепцію адаптації інституту державної служби в Україні до стандартів Європейського Союзу : Указ Президента України від 5 березня 2004 р. № 278/2004 / Президент України. Офіційний вісник Президента України. 2015. № 10. Ст. 578.

12. Основні завдання і функції Державної фіскальної служби України: Офіційний сайт Державної фіскальної служби України. URL: http: // sfs.gov.ua/pro-sfs-ukraini/zavdannya--funktsii/?print (дата звернення: 26.03.2019).

13. Дубенко С. Державна служба в Україні : навч. посібник. К.: УАДУ, 1998. 168 с.

14. Стецюк Н.М. Шляхи удосконалення управління персоналом державної служби в контексті інтеграції України в Європейський Союз. Ефективність державного управління в контексті глобалізащіï та євроінтегращџї: матеріали наук.-практ. конф. (Київ, 29 травня 2003 р.). Київ: НАДУ, 2003. С. 351-353.

15. Стецюк Н.М. Організаційні аспекти вдосконалення управління особовим складом митних органів. Державне управління: 
теорія та практика:: Електроне наукове фахахове видання НАДУ. 2005. Вип. 2. URL: http://academy.gov.ua/ej/ej2/txts/philo/ 05snmsmo.pdf (дата звернення: 26.03.2019).

16. Жигайло Н.І. Роль керівника у формуванні соціальнопсихологічного клімату в колективі. Науковий вісник Львівського університету внутрішніх справ. 2012. № 2 (1). С. 374-383.

Information about the author: Lipynskyi V. V. Candidate of Law, Associate Professor, Department of the Administrative and Customs Law, University of Customs and Finance 2/4, Vernadsky str., Dnipro, 49000, Ukraine 